\title{
The effect of vegetation type on selected soil quality indicators in a semiarid rangeland in Hamedan, Iran
}

\author{
Soheila Javaheri Khah a,*, Mohsen Nael a, Ali Akbar Safari Sinejani a, \\ Ghasem Asadian ${ }^{b}$, Khadijeh Salari Nik ${ }^{a}$ \\ a Bu-Ali Sina University, College of Agriculture, Department of Soil Science, Hamedan, Iran \\ b Agricultural and Natural Research Center of Hamedan, Iran
}

\begin{abstract}
Soil quality approach can be used to describe soil health changes caused by different land use managements and vegetation types. Our objective was to assess the response of some soil quality indicators to different vegetation types including rainfed wheat (RW), grasses $(G)$, Astragallus-Bromus (A-B), Astragallus-Lactuca (A-L), Astragallus-Artimisia (A-A) and Astragallus-Euphorbia (A-E) in a semiarid experimental rangeland in Hamedan, where environmental conditions in terms of slope aspect and soil parent material were similar., Substrate-induced microbial respiration ( $\mathrm{MRI}$ ) and the activity of phosphomonoesterase enzyme (PMEase) were determined in surface soil $(0-15 \mathrm{~cm})$ in spring and autumn. Morover, bioavailable phosphorus (P) and potassium (K) were measured in autumn. No significant disparity was detected in $\mathrm{P}$ content of different vegetation types. Bioavailable $\mathrm{K}$ between was highest in A-E, and lowest in G and RW sites. $M_{\mathrm{I}}$ was significantly higher in spring irrespective of vegetation type. This index was significantly highest in A-B site in both seasons. As for PMEase, A-A and A-B showed the highest values in autumn in spring, A-B, A-A and A-L demonstrated the highest phosphatase activity. PMEase in A-L and A-A sites was significantly higher in spring than autumn. Strongly significant positive correlation was found between PMEase and MR. Overall, soil quality is highest under vegetation types composed of perennial shrubs, irrespective of season.
\end{abstract}

Accepted : 21.11 .2014

Keywords: soil quality indicators; soil enzyme; vegetation community; substrate-induced respiration

(C) 2014 Federation of Eurasian Soil Science Societies. All rights reserved

\section{Introduction}

The interdependency of vegetation type and soil chemical and biological properties leads to a variety of species, vegetation types, and plant communities existing on a rangeland with the same parent material and single climate regime. This variety of natural vegetation types is one of the basic elements of native rangelands and is the final result of multiple interactions of several natural environmental factors. In addition, soil chemical and biological properties and, in turn, plant growth are significantly controlled by variation in landscape attributes including slope, aspect, and elevation which influence the distribution of energy, plant nutrients, and vegetation by affecting organic activity (Sanaullaha et al., 2011).

Over the last 10 years, soil quality has been one of the topics of greatest interest in soil science. This interest has been focused on defining the concept of soil quality and on searching for reliable ways for evaluating this quality (Gil-Sotres et al., 2005). Soil quality is defined as "the capacity of a specific kind of soil to function,

\footnotetext{
${ }^{*}$ Corresponding author.

Bu-Ali Sina University, College of Agriculture, Department of Soil Science, 65174-4161 Hamedan, Iran

Tel.: +988112623779

E-mail address: s.javaheri66@yahoo.com

ISSN: $2147-4249$
} 
within natural or managed ecosystem boundaries, to sustain plant and animal productivity, maintain or enhance water and air quality, and support human health and habitation".

Authors often concentrate on finding out which soil properties best reflect the change in soil quality. Even though soil quality is affected by a large number of properties, the majority choose a small group of edaphic properties (basically biological and biochemical properties) to assess soil quality (Gil-Sotres et al., 2005). Soil quality assessment by means of indices has been successfully adopted both at regional scale and on-farm level. It is believed that this kind of approach may be useful in supporting soil protection policy. Soil microbial activity, microbial respiration and enzyme activities play a key role in nutrient cycling, SOM decomposition and other soil functions (Taylor et al., 2002). These soil properties are regularly used as indicators of soil quality and fertility, and have been reported to be greatly and differently affected by different vegetation covers (Liu et al., 2010). Soil microbial properties are of great importance in determining the sustainability of agricultural management systems, and are becoming increasingly used to evaluate the influence of organic farming practices on soil quality and fertility due to their quick response, high sensitivity, ecological relevance, and ability to present information that integrates many environmental factors (Azeez et al., 2010).

Land management as well as soil and environmental conditions lead to the deployment of different plant communities in rangeland ecosystems, which in turn may have different effects on soil quality indicators. The main objective of this research was to investigate the influence of different vegetation covers on the selected chemical, physical, and biochemical soil quality indicators, and thus to discuss which soils represent the maximum or optimal level of quality under different vegetation types, in Gonbad experimental watershed, Hamadan.

\section{Material and Methods}

Paired Gonbad watershed with a total area of nearly 290 hectares is located between longitude of $48^{\circ} 41^{\prime} 5^{\prime \prime}$ and $48^{\circ} 42^{\prime} 17^{\prime \prime}$ east and latitude of $34^{\circ} 41^{\prime} 16^{\prime \prime}$ and $34^{\circ} 42^{\prime} 31^{\prime \prime}$ north, in $28 \mathrm{~km}$ south east of Hamedan (Figure 1). The watershed consists of two sub-basins: in control sub-basins no grazing management is applied, while in protected sub-basin, grazing has been restricted to a very short period in late autumn since 2002. The soil cover of the watershed consists of Typic Calcixerepts, Typic Haploxerepts and Lithic Xerorthents (Bahrami, 2012).

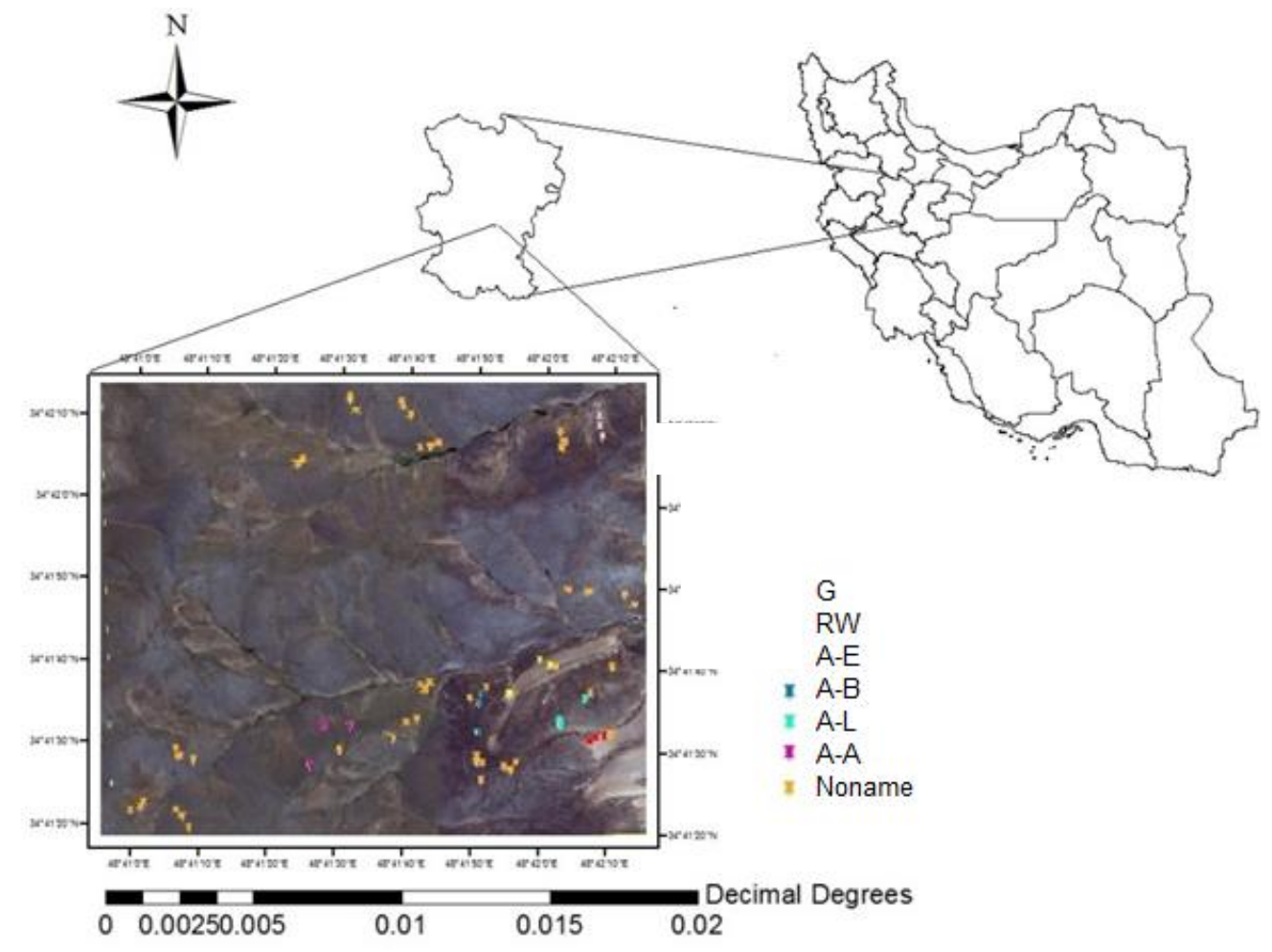

Figure 1. Location of the study area in Hamedan, Iran, and distribution of sampling plots in paired watershed of Gonbad. 
Preliminary stratification of vegetation cover was accomplished based on satellite images and field observations. Subsequently, five different vegetation types, of which grasses (G), Astragalus-Bromus (A-B), Astragalus-Artemisia (A-A), Astragalus-Lactuca (A-L) in protected sub-basin, and Astragalus-Euphorbia (AE) in control sub-basin, were selected. Plant characteristics of rangeland vegetation types are presented in Table 1. In addition, a formerly cultivated hilly land outside the watershed, now under rainfed wheat farming (RW) was selected as a nonpasture vegetation type. All of the six vegetation types were similar in terms of soil parent materials and slope aspect. Soil and plant sampling were conducted in mid-autumn 2012, and late spring 2013. Three plots $\left(1 * 1 \mathrm{~m}^{2}\right)$ were studied in each vegetation type. The annual production $\left(\mathrm{g} \cdot \mathrm{m}^{-2}\right)$ and the coverage of total canopy, annual and perennial grasses, annual and perennial forbs, and shrubs, as well as the coverage of surface gravel $(>2 \mathrm{~mm})$, litter and bare soil were measured in each plot. Moreover, the annual growth of plant cover, partitioned to the five mentioned classes, was determined. Three surface soil samples $(0-15 \mathrm{~cm})$ were collected from each plot.

Bioavailable phosphorus (Olsen et al., 1954), bioavailable potassium (Klute, 1966), substrate-induced soil microbial respiration (Alef, 1991) and phosphatase activity (Tabatabai and Bermner, 1969) were determined. A factorial experimental design with two factors, vegetation type (6 levels) and time (2 levels), was conducted. Prior to statistical analysis, data were normalized, if required.

\section{Results and Discussion}

\section{Vegetation cover}

The percentage of total vegetation canopy cover, as well as annual production of vegetation, percentage of litter, bare soil and annual forbs and grasses and perennial forbs and grasses in the different vegetation types in autumn and spring are listed in Table 1. In spring, the canopy cover increased in both preserved and overgrazed sites compared to autumn (Table 1). The highest annual production was observed in A-A and AB sites, whereas G and RW showed the lowest amount. Vegetation covers (annual and perennial grasses, annual and perennial forbs and shrubs) and total canopy covers were higher in spring than autumn, while the percentage of litter was higher in autumn. Shrub plants and perennial forbs showed larger amount in preserved rangeland; while the percent of grasses increase in overgrazed rangeland because of livestock grazing that they prefer use forb plants. Furthermore, A-B and A-A showed the highest value of total canopy cover, annual production and litter in surface soils. The low canopy cover and annual production in A-L and A-E represent adverse effects of grazing in overgrazed rangeland and also the bad effect of intensive grazing in preserved rangeland.

Table 1. The Mean comparison of annual production (g.m-2), total canopy cover (\%), shrub cover (\%), perennial grasses $(\%)$, annual grasses (\%), perennial forbs (\%), annual forbs (\%), litter (\%) and bare soil in different vegetation types.

\begin{tabular}{|c|c|c|c|c|c|c|c|c|c|}
\hline $\begin{array}{l}\text { Vegetation } \\
\text { type }\end{array}$ & $\begin{array}{l}\text { Annual } \\
\text { production } \\
\left(\mathrm{g} \cdot \mathrm{m}^{-2}\right)\end{array}$ & $\begin{array}{l}\text { Total } \\
\text { canopy } \\
\text { cover } \\
(\%) \\
\end{array}$ & $\begin{array}{l}\text { Shrub } \\
\text { plants } \\
(\%)\end{array}$ & $\begin{array}{l}\text { Perennial } \\
\text { grasses } \\
(\%)\end{array}$ & $\begin{array}{l}\text { Annual } \\
\text { grasses } \\
(\%)\end{array}$ & $\begin{array}{l}\text { Perennia } \\
\text { l forbs } \\
(\%)\end{array}$ & $\begin{array}{l}\text { Annual } \\
\text { forbs } \\
(\%)\end{array}$ & $\begin{array}{l}\text { Litter } \\
(\%)\end{array}$ & $\begin{array}{l}\text { Bare } \\
\text { soil (\%) }\end{array}$ \\
\hline RW*spring & - & - & - & - & - & - & - & $0.0^{c}$ & $99.5^{\mathrm{a}}$ \\
\hline RW*autumn & - & - & - & - & - & - & - & $6.6^{\mathrm{bc}}$ & $92.6^{\mathrm{cd}}$ \\
\hline G*spring & $20.45^{\mathrm{ab}}$ & $30.0^{d}$ & $10.7^{b c d e}$ & $0.6^{\mathrm{b}}$ & $5.0^{\text {bcde }}$ & $10.3^{\mathrm{a}}$ & $3.3^{\mathrm{ab}}$ & $2.8^{c}$ & $58.8^{\mathrm{cd}}$ \\
\hline $\mathrm{G}^{*}$ autumn & - & $28.0^{\mathrm{d}}$ & $0.9^{\mathrm{e}}$ & $0.3^{\mathrm{b}}$ & $0.2^{\mathrm{de}}$ & $11.9^{a}$ & $0.0^{c}$ & $15.3^{c}$ & $51.2^{\text {cde }}$ \\
\hline A-B*spring & $83.03^{\mathrm{ab}}$ & $66.6^{\mathrm{ab}}$ & $24.0^{\mathrm{abc}}$ & $28.3^{a}$ & $11.3^{\mathrm{ab}}$ & $7.0^{\mathrm{a}}$ & $0.0^{c}$ & $12.3^{\mathrm{ab}}$ & $19.6^{\mathrm{ef}}$ \\
\hline A-B*autumn & - & $56.1^{\mathrm{bc}}$ & $18.3^{\mathrm{abcd}}$ & $13.0^{\mathrm{b}}$ & $10.8^{\mathrm{abc}}$ & $14.0^{\mathrm{a}}$ & $0.0^{c}$ & $16.0^{\mathrm{a}}$ & $26.1^{\mathrm{def}}$ \\
\hline A-L*spring & $45.03^{\mathrm{bc}}$ & $32.0^{\mathrm{d}}$ & $10.7^{b c d e}$ & $1.7^{b}$ & $14.7^{\mathrm{a}}$ & $3.7^{\mathrm{a}}$ & $0.0^{c}$ & $1.8^{c}$ & $54.1^{\mathrm{cd}}$ \\
\hline A-L*autumn & - & $24.5^{\mathrm{d}}$ & $13.0^{\mathrm{bcde}}$ & $0.0^{\mathrm{b}}$ & $5.8^{\text {bcde }}$ & $5.3^{\mathrm{a}}$ & $0.0^{c}$ & $8.1^{c}$ & $52.1^{\text {cde }}$ \\
\hline A-E*spring & $50.23^{b c}$ & $22.8^{\mathrm{de}}$ & $5.3^{\mathrm{de}}$ & $4.7^{b}$ & $6.0^{\text {bcde }}$ & $3.3^{\mathrm{a}}$ & $1.3^{\mathrm{bc}}$ & $2.1^{\mathrm{c}}$ & $65.5^{\mathrm{bc}}$ \\
\hline A-E*autumn & - & $22.7^{\mathrm{de}}$ & $9.4^{\text {cde }}$ & $7.3^{\mathrm{b}}$ & $1.0^{\mathrm{de}}$ & $5.0^{\mathrm{a}}$ & $0.0^{\mathrm{c}}$ & $1.5^{\mathrm{c}}$ & $65.8^{\mathrm{bc}}$ \\
\hline A-A*spring & $109.74^{\mathrm{a}}$ & $81.3^{\mathrm{a}}$ & $29.3^{\mathrm{a}}$ & $39.0^{\mathrm{a}}$ & $8.7^{\mathrm{abcd}}$ & $0.0^{\mathrm{a}}$ & $0.0^{c}$ & $2.5^{\mathrm{c}}$ & $13.0^{\mathrm{f}}$ \\
\hline A-A*autumn & - & $43.3^{\mathrm{cd}}$ & $27.7^{\mathrm{ab}}$ & $9.3^{\mathrm{b}}$ & 2.7 cde & $3.7^{\mathrm{a}}$ & $4.3^{\mathrm{a}}$ & $5.0^{\mathrm{bc}}$ & $35.6^{\text {cdef }}$ \\
\hline
\end{tabular}

\section{Impact of different vegetation type on soil quality indices}

The biological and chemical indicators of soil quality are shown in Table 2 . K and P values ranged from 169.4 to 271.1 and 14 to $23.3 \mathrm{mg} / \mathrm{kg}$, respectively. No significant disparity was detected in P content of different vegetation types (Figure 2A). Inorganic form of phosphorus has a large portion of the bioavailable P; the similarity of the soil parent material in different vegetation types and considering the lower proportion of 
organic $\mathrm{P}$ on bioavailable phosphorus concentration, the effect of vegetation type on bioavailable $\mathrm{P}$ differences were not significant. Soil bioavailable $\mathrm{K}$ depends on soil mineralogy. The highest bioavailable $\mathrm{K}$ was detected in A-E site; so increasing bioavailable potassium amount is due to the soil texture of A-E which was clay soil. This element appeared to be significantly lowest in RW (169.4 mg.kg-1) (Table2). Lack of permanent vegetation cover, continued wheat cultivation, uptake this element by plants and finally harvesting may explain the reduction of bioavailable $\mathrm{K}$ in the farmland site.

Table 2.The mean comparison of selected soil biological and chemical indicators.

\begin{tabular}{|c|c|c|c|c|c|c|c|}
\hline 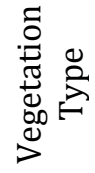 & Land Use & $\begin{array}{l}\mathrm{K} \\
(\mathrm{mg} / \mathrm{kg})\end{array}$ & $\begin{array}{l}\mathrm{P} \\
(\mathrm{mg} / \mathrm{kg})\end{array}$ & $\begin{array}{l}\text { PMEase } \\
\text { activity in } \\
\text { autumn } \\
\left(\mu \mathrm{mol} \mathrm{g}{ }^{-1} \mathrm{~h}^{-1}\right)\end{array}$ & $\begin{array}{l}\text { PMEase } \\
\text { activity } \\
\text { in spring } \\
\left(\mu \mathrm{mol} \mathrm{g}{ }^{-1} \mathrm{~h}^{-1}\right)\end{array}$ & $\begin{array}{l}\text { MRI in } \\
\text { autumn } \\
\text { (mg co } 2 . g \\
\text { soil }^{-1} \text { day }^{-1} \text { ) }\end{array}$ & $\begin{array}{l}\text { MRI in } \\
\text { spring } \\
\text { (mg co2.g } \\
\text { soil }^{-1} \text { day }^{-1} \text { ) }\end{array}$ \\
\hline RW & rainfed farm & $169.45^{b}$ & $14.00^{\mathrm{a}}$ & $1.053^{\mathrm{d}}$ & $1.069^{\mathrm{cd}}$ & $0.364 \mathrm{e}$ & $0.697^{\mathrm{ab}}$ \\
\hline $\mathrm{G}$ & preserved rangeland & $175.45^{b}$ & $21.33^{a}$ & $1.091^{\mathrm{cd}}$ & $1.080^{\mathrm{cd}}$ & 0.427 cde & $0.691^{\mathrm{ab}}$ \\
\hline$A-B$ & preserved site & $221.34^{\mathrm{ab}}$ & $20.66^{a}$ & $1.185^{\mathrm{bcd}}$ & $1.275^{\mathrm{b}}$ & $0.554^{b c}$ & $0.778^{a}$ \\
\hline A-L & preserved site & $235.51^{\mathrm{ab}}$ & $23.33^{a}$ & $1.073^{\mathrm{cd}}$ & $1.432^{\mathrm{a}}$ & $0.547 \mathrm{bcd}$ & $0.777^{a}$ \\
\hline A-E & Overgrazed rangeland & $271.16^{\mathrm{a}}$ & $21.33^{\mathrm{a}}$ & $1.058^{\mathrm{d}}$ & $1.259^{b}$ & $0.379^{\mathrm{ed}}$ & $0.706^{\mathrm{ab}}$ \\
\hline$A-A$ & preserved site & $247.22^{\mathrm{ab}}$ & $19.11^{\mathrm{a}}$ & $1.216^{\mathrm{bc}}$ & $1.447^{\mathrm{a}}$ & $0.453^{\text {cde }}$ & $0.759^{a}$ \\
\hline
\end{tabular}

K: bioavailable potassium, P: bioavailable phosphorus, PMEase: phosphomonoesterase enzyme, MR $_{1:}$ substrate-induced microbial respiration. Different superscripts indicate significantly different means $(\alpha=0.05)$.

PMEase activity ranged from 1.05 to 1.21 and 1.06 to $1.44\left(\mu \mathrm{mol} p\right.$-Nitrophenol $\left.\mathrm{g}^{-1} \mathrm{~h}^{-1}\right)$ in autumn and spring, respectively (Table 2). A-A clearly showed the highest phosphatase activity. PMEase in A-B showed to be significantly higher compared to G, RW, A-L and A-E types in autumn; while in spring, A-B, A-A and A-L demonstrated the highest content of PMEase (Table 2). Phospatase activity is implied in P cycle (Taylor et al., 2002). Some of the enzymes like phosphomonoesterases convert organic phosphate to inorganic form.
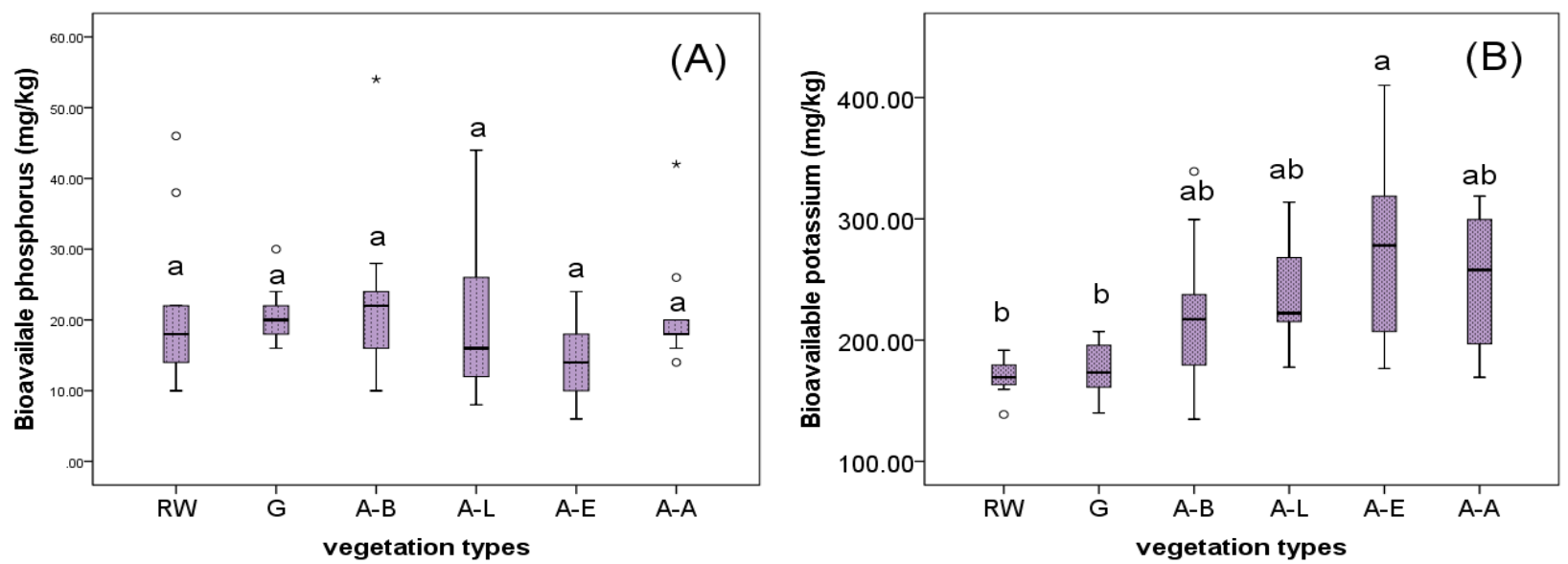

Figure 2. (A) Soil bioavailable phosphorus (mg.kg-1) and (B) soil bioavailable potassium (mg.kg-1) under different
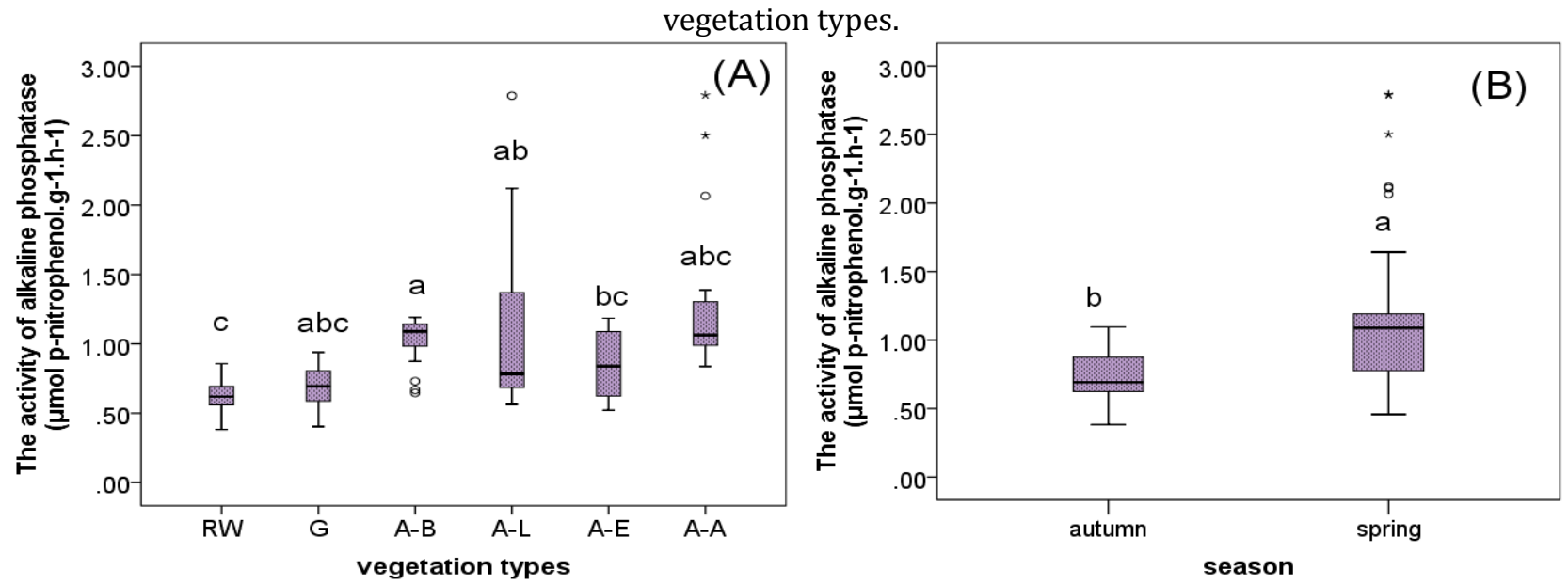

Figure 3. (A) The activity of soil alkaline phosphatase $\left(\mu \mathrm{mol} \cdot \mathrm{g}^{-1} \cdot \mathrm{h}^{-1}\right)$ under different vegetation types (two seasons mean). (B) The activity of soil alkaline phosphatase $\left(\mu \mathrm{mol} \cdot \mathrm{g}^{-1} \cdot \mathrm{h}^{-1}\right)$ in autumn and spring in vegetation types. 

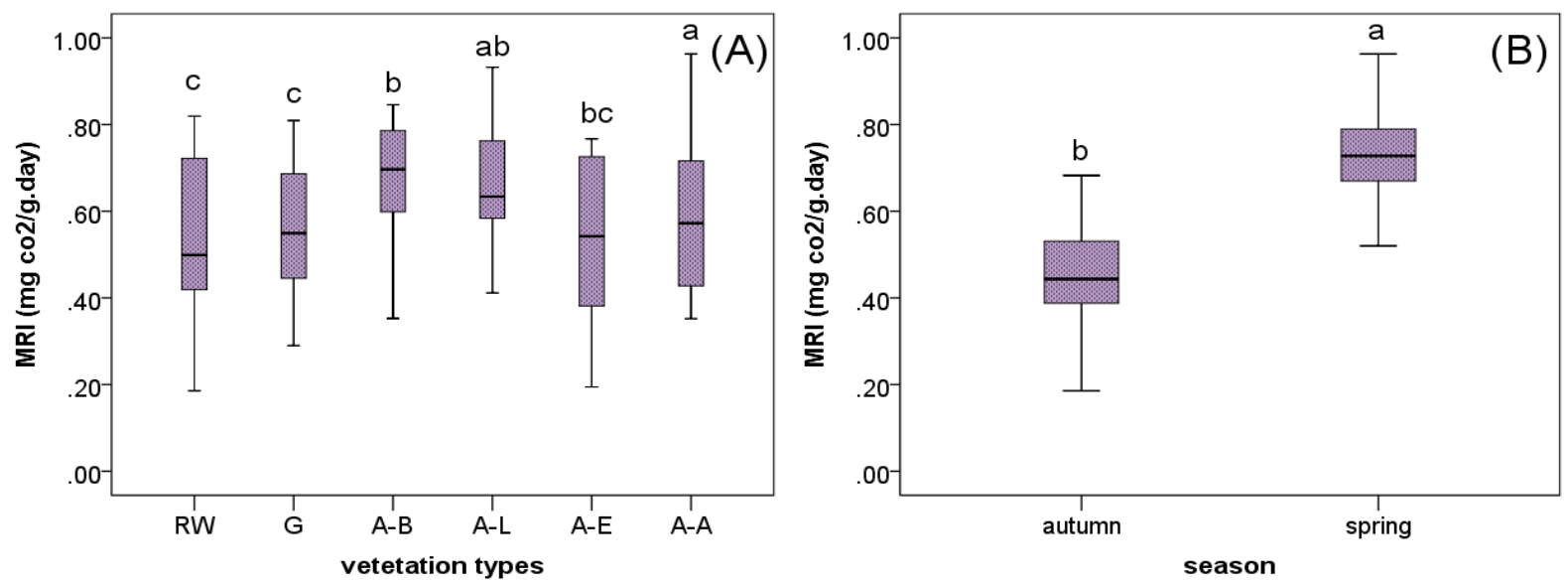

Figure 4. (A) Soil substrate-induced microbial respiration (MRI) (mg co2. $\left.\mathrm{g}^{-1} \cdot \mathrm{d}^{-1}\right)$ under different vegetation types. (B) Soil substrate-induced microbial respiration ( $\left.\mathrm{mg} \mathrm{co}_{2} \cdot \mathrm{g}^{-1} \cdot \mathrm{d}^{-1}\right)$ in autumn and spring in vegetation types.

Phosphatase activity is largely associated with the organic matter components (Chaer et al., 2009). High vegetation cover and litter in A-A culminates in higher production of root and microbial exudates which, in turn, lead to the higher enzyme activity in this site. No significant differences were observed between A-B, AL and A-E sites; while the lowest phosphatase activity was measured in RW site (Figure 3A). Sanaullaha et al. (2011) reported that the activity of extracellular enzymes were higher in rangelands compared to farmlands. The average $\mathrm{MR}_{1}$ in different vegetation types and seasons ranged from 0.36 to 0.77 (mg co .g soil $^{-1}$.day ${ }^{-1}$ ). Substrate-induced microbial respiration is a sensitive biological indicator to determine the impacts of environmental variables on soil microbial activities. $\mathrm{MR}_{\mathrm{I}}$ showed significant differences between different vegetation types in two seasons (Table2). A-B and A-L exhibited the highest amount of $\mathrm{MR}_{1}$ (Figure 4A). Excessive microbial respiration in rangeland is due to high amount of organic matter and added fresh matter to the soil. A-E in the overgrazed rangeland had the lowest amount of $\mathrm{MR}_{1}$.

\section{Seasonal changes of soil quality indices}

PMEase activity was significantly higher in spring compared to autumn, which can be attributed to an increase in vegetation cover (Table 2). Moreover, canopy cover throws shade over the soil in spring, which is a suitable condition for the survival and reproduction of soil microorganism; the enzyme activity will increase in this season as well. Sanaullaha et al. (2011) found a significant increase in the activity of soil enzymes in spring (10). $\mathrm{MR}_{1}$ was significantly higher in spring compared to autumn (Figure $4 \mathrm{~B}$ ). A-A and A-B showed the highest amount of $\mathrm{MR}_{1}$ in spring (0.759 and $0.778 \mathrm{mg} \mathrm{co}_{2} . \mathrm{g}^{-1}$ soil-1.day-1, respectively), while in autumn, A-L had the highest amount of this indicator $\left(0.547 \mathrm{mg} \mathrm{co}_{2} . \mathrm{g} \mathrm{soil}^{-1} . \mathrm{day}^{-1}\right)$.

\section{Relationships between soil quality indicators and vegetation-environmental factors}

Multivariate linear regression equation was applied to quantify the relationship between soil quality indicators, as dependent variable, vegetation-environmental factors. In autumn, 70\% variation of PMEase activity is explained by shrub cover. , $40 \%$ variation of $\mathrm{MR}_{1}$ by top soil stone, $36 \%$ variation of $\mathrm{P}$ by bare soil, and finally $41 \%$ variation of $\mathrm{K}$ by annual production. In spring, $70 \%$ variation of PMEase activity is explained by total canopy cover, and $62 \%$ variation of $\mathrm{MR}_{1}$ by total canopy cover.

\section{Conclusion}

Vegetation cover in A-B and A-A was observed in highest amount. Hence, vegetation cover is greater and so C inputs in soil as litter. It seems evident that $A-A$ and $A-B$ vegetation types increased soil elements like $P, K$ and their dynamics. PMEase activity and $\mathrm{MR}_{1}$ changed in different season. Generally, with increasing the vegetation cover percentage in rangeland most of the soil biological properties were improved to a large extent and shrubs had the greatest effect on these soil properties. The result show that pasture and agricultural land management has a direct impact on soil. In conclusion, the presence of plant increases the activity and biomass of soil microflora over the growing season, leading to improved condition in semi-arid soils of west Iran. 


\section{References}

Alef, K, 1991. Methodenhandbuch bodenmicrobiologie. Ecomed-vertagsgesellschaft, Landsberg.

Azeez, J.O., Averbeke, W.V., Okorogbona, A.O.M., 2010. Differential responses in yield of pumpkin (Cucurbita maxima L.) and nightshade (Solanum retroflexum Dun.) to the application of three animal manures. Bioresource Technology 101: 2499-2505.

Bahrami, A., 2012. The effect of aspect on some soil quality indicators in Gonbad basin watershed, Hamedan. Master's theses. Bu Ali-Sina university, Iran.

Chaer, G.M., Myrold D.D., Bottomley, P.J., 2009. A soil quality index based on the equilibrium between soil organic matter and biochemical properties of undisturbed coniferous forest soils of the Pacific Northwest. Soil Biology and Biochemistry 41: 822-830.

Gil-Sotres, F., Trasar-Cepeda, C., Leiro's, M.C., Seoane, S., 2005. Different approaches to evaluating soil quality using biochemical properties. Soil Biology and Biochemistry 37: 877-887.

Klute, A., 1966. Methods and soil analysis. Soil Science Society America. pp.432-449.

Liu, E., Yan, C., Mei, X., He, W., Bing, S.H., Ding, L., Liu, Q., Liu, S., Fan, T., 2010. Long-term effect of chemical fertilizer, straw, and manure on soil chemical and biological properties in northwest China. Geoderma 158: 173-180.

Olsen, R.S., Cole, V.C., Watanabey, F.S., Dean, L.A. 1954. Estimation of available phosphorus in soils by extraction with sodium bicarbonate. US Department of Agricultural Circulation. p. 939.

Rezaei, S.A., Gilkes, R.J., 2005. The effects of landscape attributes and plant community on soil chemical properties in rangelands. Geoderma 125: 167-176.

Sanaullaha, M., Blagodatskaya, E., Chabbi, A., Rumpel, C., Kuzyakov, Y., 2011. Drought effects on microbial biomass and enzyme activities in the rhizosphere of grasses depend on plant community composition. Applied Soil Ecology 48: 38-44.

Tabatabai, M.A., Bermner, J.M., 1969. Use of $\rho$-nitro-phenyl phosphate for Assay of Soil Phosphatase Activity. Soil Biology and Biochemistry 1: 301-307.

Taylor, J.P., Wilson, M., Mills, S., Burns, R.G., 2002. Comparison of microbial numbers and enzymatic activities in surface soils and subsoils using various techniques. Soil Biology and Biochemistry 34: 387-401.

Vineela, C., Wani, S.P., Srinivasarao, C., Padmaja, B., Vittal, K.P.R., 2008. Microbial properties of soils as affected by cropping and nutrient management practices in several long-term manurial experiments in the semi-arid tropics of India. Applied Soil Ecology 40: 165-173. 